\title{
A Study on the Training Mode of Electronic Application- Oriented Undergraduate with Industry Needs
}

\author{
Zhonghua Wang ${ }^{1} \nless$ if \\ Lifang Cheng' ${ }^{2}$ (D) \\ Hao Wang ${ }^{3}$ \\ ${ }^{1,3}$ School of Information Engineering, Nanchang Hangkong University, Nanchang, China \\ ${ }^{2}$ Basic Courses Department, Air Force Early-warning Academy, Wuhan, China
}

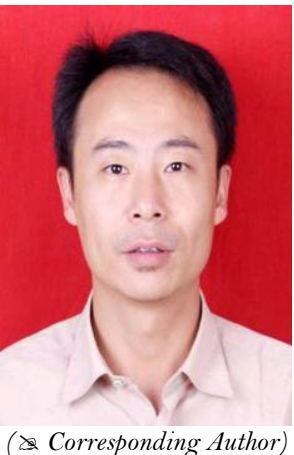

\begin{abstract}
Electronic industry is an economic pillar in China. Due to the Moore's Law, the industry requires continuous development and innovation. In order to achieve these goals, the cultivation of electronic application-oriented undergraduate is essential. However, at current, the innovative educational concepts and teaching methods are lagging behind so that the graduates cannot meet the requirements of electronic industry. In this paper, we adopt a variety of measures, which include the construction of parallel course system, the establishment of cooperative education mechanics and the creation of training evaluation mode, to improve the training quality of electronic application-oriented undergraduate. The research findings show that the undergraduates improve their engineering practices and innovation abilities.
\end{abstract}

Keywords: Education concepts, Excellent engineer, Electronic engineering education, Applied talents.

Citation | Zhonghua Wang; Lifang Cheng; Hao Wang (2017). A Study on the Training Mode of Electronic Application- Oriented Undergraduate with Industry Needs. Journal of Education and eLearning Research, 4(2): 37-40.

History:

Received: 11 April 2017

Revised: 2 May 2017

Accepted: 18 May 2017

Published: 1 June 2017

Licensed: This work is licensed under a Creative Commons

Attribution 3.0 License $(\mathrm{cc})$

Publisher:Asian Online Journal Publishing Group
Contribution/Acknowledgement: The authors gratefully thank the reviewers for their useful comments that lead to quality improvements of the paper.

Funding: This work is supported by the Educational Science Planning Project of Jiangxi Province of China under Grant No. 16YB086, the Innovation and Entrepreneurship Training Program of Digital Circuit and Logic Design of Nanchang Hangkong University of China under Grant No. KCPY 1620.

Competing Interests: The authors declare that they have no conflict of interests.

Transparency: The authors confirm that the manuscript is an honest, accurate, and transparent account of the study was reported; that no vital features of the study have been omitted; and that any discrepancies from the study as planned have been explained.

Ethical: This study follows all ethical practices during writing.

\section{Contents}

1. Introduction

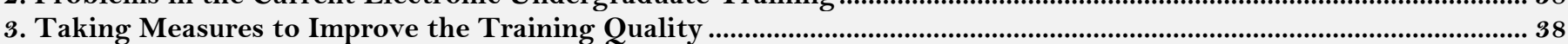

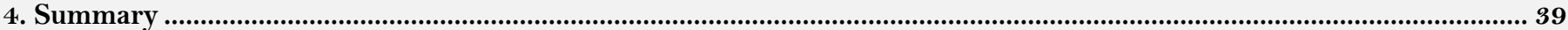

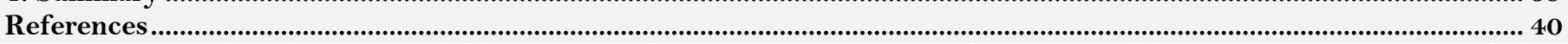




\section{Introduction}

As the different historical and cultural customs, the different level of economic and social development all around the world, the education development mode of each country is also different. Though the high education scale, especially the scale of engineering education in china is ranked first in the world, the engineering training quality still exists a big gap with the world top-ranking level, cited from the Switzerland report, "World Competitiveness Report” (Slavin, 1991; Hamilton, 1999; Krugman, 2002).

The capitalism power, led by the United States and the United Kingdom, has developed new policies and programs to promote the development of high-quality engineering talent while gain insight into the engineering trends. In 2004 and 2005 year, the US national academy of engineering and the US natural science foundation committee successively published the "2020 engineers: the vision of the new century project" and "training 2020 engineers: for the new century, change engineering education" report (Iturbe et al., 2005; Corr et al., 2015). The publication of "industry-oriented engineering graduates" in 2010 year and "industry-oriented engineering graduates" report in 2007 year, released by the british royal college, pointed out that the British engineering education must strengthen the education link of industry and engineering undergraduate since the industry especially needs the engineering graduates with practice experience (Felder and Silverman, 1988; Pajares, 1992; Aldrich, 2005).

Electronic information industry is the pillar industry of China's economy, in the global economic downturn and domestic economy slowdown, the electronic information industry continues to maintain a rapid growth rate. Since the electronic information industry is a technology-intensive industry, and in recent years, the interdiscipline research of internet of things has been realized a certain breakthrough, the electronics industry poses new challenges to the practitioner's professionalism and knowledge reserve (LiJuan, 2005; Wang and Zhou, 2010).

However, the main problems in the electronic undergraduate training in China are as follows. First, treasuring the theoretical study but ignoring the practice ability training in teaching mode. Second, the undergraduates are the passive learning and negative blind obedience. So, the above disadvantages seriously restrict the cultivations of engineering and technical talents. In order to improve the electronic application-oriented undergraduate's ability, we must take measures that are prone to the electronic industry development.

\section{Problems in the Current Electronic Undergraduate Training}

For higher education, the goal is to continuously improve the graduate's training quality. Under the current situation, the main problems in the training for engineering talents of electronic application in China are the backwardness of innovative education concepts and innovative teaching modes, the lack of teachers with engineering background and the shortage of training platform for practice [9].

The problems studied in this paper are as follows.

(1) Undergraduate's autonomy, initiative and creativity cannot be effectively exerted

The undergraduate's innovative ability is reflected in the aspects of autonomy, initiative and creativity. At present, the wide-caliber talent training mode, the assimilative training curriculum system has neglected the development of undergraduate's individuality. The talent training in colleges and universities should not only enhance the undergraduate's scientific and cultural knowledge, but also cultivate the student's initiative and creativity. However, the current teaching mode still continues to implement the "spoon feeding" pattern.

(2) The curriculum system does not meet the needs of the society and industry

During the rapid development of Chinese higher education from the elite to the popularization, the wide caliber training mode weakens the professional characteristics and makes the training mode convergent. In the meantime, the curriculum system only focuses on the basic theory and basic quality training, and ignores the innovation ability. So, the graduates cannot well meet the industry needs.

(3) The practical task of adapting to the needs of the industry have not been fully implemented

At present, the graduates are reflected the poor ability of engineering practice, who often requires a long period of adaptation to undertake their job smoothly, since the undergraduates only learn from book or internet and lack the practical training during college years, which are far from enough towards the engineering undergraduates.

\section{Taking Measures to Improve the Training Quality}

With the rapid development of the global economy, the development speed of new technology is also accelerating. So, the theoretical knowledge of engineering has been accumulated more and more, which affects people's production and lifestyle continuously. As main disciplinary basis, the technical science takes cultivating engineers as the core goal, which is a comprehensive education process in essence. The aim of training engineers is to realize the ability of solving practical engineering problems. It not only has the general characteristics of higher education, such as "education, specialization and academic nature", but also has the particularity of "application, technicality and practicality”.

Scientific knowledge, especially in the field of engineering, whose replacement speed is fast, while the updating of basic knowledge is relatively slow. Therefore, the electronic students must be targeted to enhance their ability to solve practical engineering problems and should spend more time mastering the latest technology in engineering.

The teaching, learning and training of electronic application-oriented talents should focus on cultivating students' innovation and practical ability. Under the premise of recognizing the individual differences of students, the industry standards should be introduced, the overall design of the training programs must be strengthened and the module teaching could be implemented, then we can set up the teaching pattern of high-quality engineering and technical talent.

The route is divided into three progressive levels. First, establishing the training objectives and specifications of industry talent. Second, formulating the training programs of industry talent. Third, taking measures to cultivate the undergraduates. Its specific framework is shown in Figure 1. 


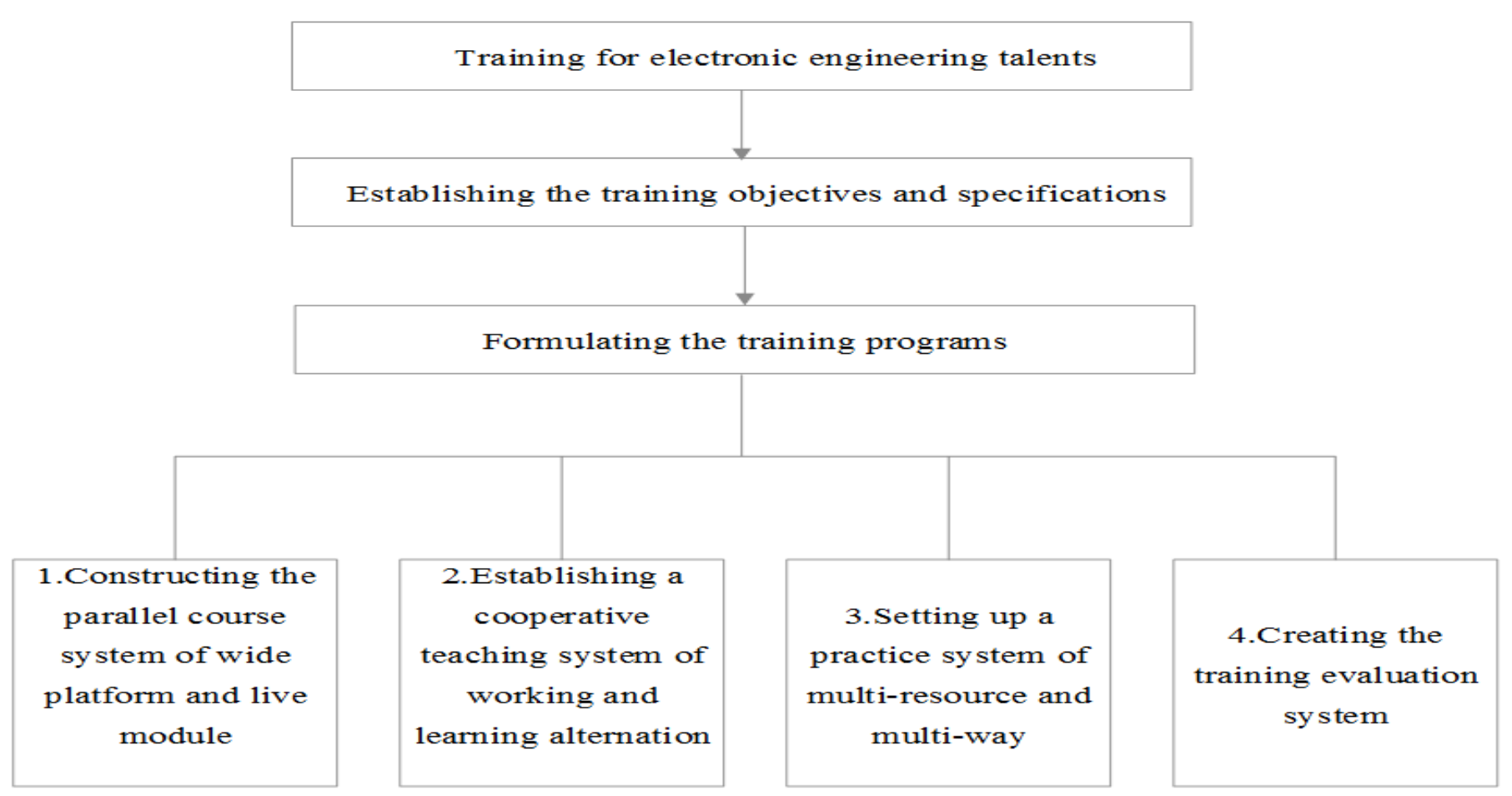

Figure-1. A research framework for training the electronic applied talents

The training goal is the "pointer" of training mode. If the "pointer" direction is accurate, the development of training programs can have a positive role in talent training. Then, the establishment of the training objectives must be organically linked with the industrial demand. In order to meet the needs of the industry, we should emphasize the engineering background education and set up the curriculum system of the diversified talent training programs, which reflect the principles of the diversity, characteristics, guidance, engineering and application.

(1) Constructing the parallel course system of wide platform and live module

Emphasizing the relevance and comprehensiveness of public basic courses, professional basic courses and professional courses, a curriculum system of wide platform and live module is built. The wide platform means the wide-caliber professional basic courses and the live modules are the flexible and professional curriculum modules. Taking into account the systematicness and flexible adaptability of training programs, and establishing a reasonable curriculum system, we can provide the training for different development direction.

(2) Establishing the cooperative education system

The mode of work-study alternation is a kind of cooperative education mode, which is based on the educational resources of the school and the technical resources of the enterprise. The practice runs through the undergraduate course system and is divided into the term of theoretical knowledge learning in school and the term of practical training and scientific research training in and out of school.

(3) Setting up the multi-resource and multi-way practice system

The essence of higher engineering education is engineering practice. Taking "Learning by Doing" as a concept, we let the students play the main role and build open experimental teaching mode, production-practice mode and large-scale comprehensive experiment mode. Through the mechanism of school-enterprise cooperation based on two-way participation and complementary advantages, we explore the training progressive mode of applicationoriented talent, which includes the school-enterprise joint training stage. In short, its purpose is to actively create a platform for training the scientific and technological innovation ability of college student.

(4) Creating the training evaluation system

The training evaluation quality should have not only the function of comprehensive and effective evaluation of undergraduate's achievement but also the function of promoting the common development of undergraduates and enterprises, while the latter is undoubtedly most important function. The evaluation system should include the evaluation of the project environment, the student's subjectivity, the student's introspection and the task diversification. In the training process, the undergraduates can gradually find self, realize self and transcend self, then become useful talents of industry construction.

\section{Summary}

As long as the teaching mode highlights the needs of the industry or expands the student's theoretical knowledge and engineering practice experience, it is a good mode. As educators, what we have to do is keeping pace with the times, introducing new methods and adjusting the teaching mode to adapt to the needs of the electronics industry.

With the implementation of industry demand and excellent engineer plan as the breakthrough point, the training objectives of different colleges and universities can be different, but the development of undergraduate's individuality must be fully encouraged. So, we must strive to train the electronic application-oriented undergraduates, however, it has a long way to go. 


\section{References}

Aldrich, C., 2005. Learning by doing: A comprehensive guide to simulations, computer games, and pedagogy in e-Learning and other educational experiences. Jossey-Bass Inc. Publishers.

Corr, P.J., C.G. Deyoung and N. Mcnaughton, 2015. Motivation and personality. Social and Personality Psychology Compass, 1: 187-202.

Felder, R.M. and L.K. Silverman, 1988. Learning and teaching styles in engineering education. Journal of Engineering Education, 78(7): 674681. View at Google Scholar

Hamilton, S., 1999. Taking Moore's law into the next century. Computer, 32(1): 43-48. View at Google Scholar $\mid$ View at Publisher

Iturbe, C.B., L.M.L. Ochoa and M.C.J. Castello, 2005. Educating the engineer of 2020: Adapting engineering education to the new century. National Academies Press, 37(1): 11.

Krugman, P., 2002. The world competitiveness report. Management Services, 3: 161.

LiJuan, Y., 2005. On undergraduate course education quality guarantee system for sustained promotion of ability of talent cultivation. Journal of Shanghai Physical Education Institute, 5: 001. View at Google Scholar

Pajares, M.F., 1992. Teachers' beliefs and educational research: Cleaning up a Messy Construct. Review of Educational Research, 62(3): 307332. View at Google Scholar | View at Publisher

Slavin, R.E., 1991. Synthesis of research of cooperative learning. Educational Leadership, 48(5): 71-82. View at Google Scholar

Wang, M. and M. Zhou, 2010. Development of the training program for excellent advanced manufacturing technology engineers by projectteaching method. China Modern Educational Equipment, 12: 15-19. 